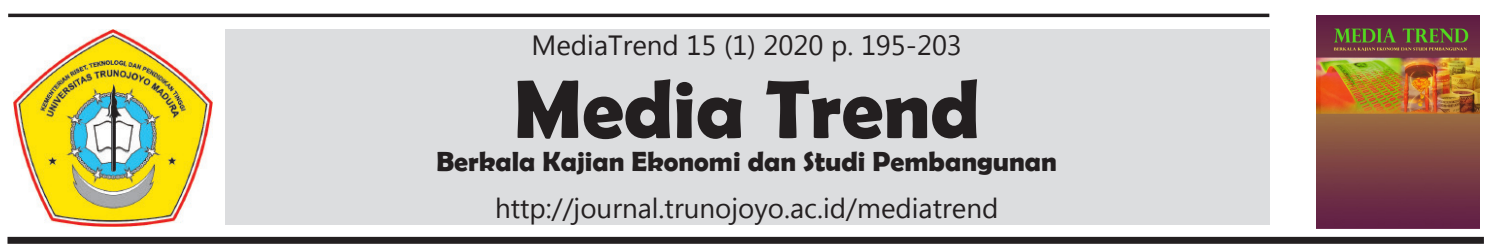

\title{
Model Pengembangan Pelayanan Desa Terintegrasi (Studi pada Kabupaten Banyuwangi dan Bondowoso Provinsi Jawa Timur)
}

\author{
Nian Riawati ${ }^{*}$ \\ ${ }^{1,2}$ Faculty of Social and Political Science, University of Jember
}

\begin{tabular}{l} 
Informasi Artikel \\
\hline Sejarah artikel: \\
Diterima Desember 2019 \\
Disetujui Februari 2020 \\
Dipublikasikan Maret \\
2020 \\
\hline Keywords: \\
Government, \\
Information Technology, \\
Independent Village
\end{tabular}

\footnotetext{
Penulis korespondensi:

E-mail: nian.fisip@unej.ac.id

DOI: http://dx.doi.org/10.21107/mediatrend.v15i1.6174

2460-7649 (c) 2020 MediaTrend. All rights reserved.

Penulis korespondensi:
}

\begin{abstract}
ABS TR ACT
This study describes the practice of E-Government in the regions through the Smart Village Program in Banyuwangi district and the Village Information Administration System (SAID) Program in the Bondowoso district. By using descriptive qualitative research methods, this study can describe the context and set it naturally. The results showed that the smart village program in Banyuwangi District and the SAID Program in Bondowoso District could realize independent villages in data and information and could improve the quality of services to the community for the better. The town has a database that used as a reference for the district government in making empowerment policies and making services to the city faster, easier, and cheaper. There are some problems in its implementation, such as remote villages that do not yet have an internet network, the low competence of human resources in the town, the weak
\end{abstract}

\section{A B S T R A K}

Studi ini menggambarkan praktik E-Government di daerah melalui Program Desa Pintar di Kabupaten Banyuwangi dan Program Sistem Administrasi Informasi Desa (SAID) di Kabupaten Bondowoso. Dengan menggunakan metode penelitian kualitatif deskriptif, penelitian ini dapat menggambarkan konteks dan mengaturnya secara alami. Hasil penelitian menunjukkan bahwa program desa pintar di Kabupaten Banyuwangi dan Program SAID di Kabupaten Bondowoso dapat mewujudkan desa mandiri dalam data dan informasi dan dapat meningkatkan kualitas layanan kepada masyarakat menjadi lebih baik. Kota ini memiliki database yang digunakan sebagai referensi bagi pemerintah kabupaten dalam membuat kebijakan pemberdayaan dan membuat layanan ke kota lebih cepat, lebih mudah, dan lebih murah. Ada beberapa masalah dalam implementasinya, seperti desa-desa terpencil yang belum memiliki jaringan internet, rendahnya kompetensi sumber daya manusia di kota, lemahnya dukungan dari pemerintah desa, dan kurangnya fasilitas dan infrastruktur.

(C) 2020 MediaTrend 


\section{PENDAHULUAN}

Adopsi teknologi informasi oleh pemerintah atau yang disebut e-government merupakan suatu hal yang mutlak. E-government diartikan sebagai the use of computers and the internet by government of information and communication technologies to deliver information and services to citizens, businesses, and other stakeholders (DeLone dan McLean, 2013). Dalam pengertian ini e-government memiliki makna sebagai penggunaan sarana teknologi informasi oleh pemerintah dalam rangka penyampaian informasi dan penyelenggaraan pelayanan kepada masyarakat, bisnis dan berbagai pihak yang berkepentingan (Anthopoulos dkk, 2016). Dengan demikian maka e-government memiliki dua fungsi yaitu arus informasi dan juga proses pelayanan.

Penelitian ini mendeskripsikan dan menganalisis E-Goverment sebagai cara bagi pemerintah dalam penggunaan teknologi informasi dan komunikasi yang inovatif melalui penggunaan aplikasi internet berbasis web (Larson and Grounlund, 2014). Tujuan nya adalah untuk memperbaiki kualitas layanan kepada warga $\mathrm{Ne}$ gara untuk memberikan akses informasi dan juga memberikan kesempatan untuk berpartisipasi dalam institusi dan proses demokrasi. Ini termasuk transaksi antara pemerintah dan bisnis, pemerintah dan warga negara, pemerintah dan karyawan, dan di antara berbagai unit dan tingkat pemerintahan (El-Haddadeh, 2013). Ebusiness dan e-commerce adalah himpunan bagian dari e-government. E-government menghadirkan dorongan luar biasa untuk maju di abad 21 dengan kualitas, biaya, efektif, pelayanan pemerintah dan hubungan yang lebih baik antara antara warga negara dan pemerintah (Sa dkk, 2015).

Kabupaten Banyuwangi dan Bondowoso merupakan daerah di provinsi Jawa timur yang berinovasi melalui penggunaan tekhnologi informasi untuk mem- berikan pelayanan kepada masyarakat. Program pengembangan sistem elektronik yang sudah dilakukan di Kabupaten Banyuwangi diantaranya e-office, e-planing, ebudgeting, e-procurement, e-performance dan e-audit. Contoh Program yang di kembangkan yaitu program smart kampung dan e-commerce. Program smart kampung merupakan Program pengembangan desa terintegrasi yang memadukan antara penggunaan teknologi informasi berbasis serat optik, kegiatan ekonomi produktif dan kegiatan ekonomi kreatif.

Kabupaten Banyuwangi telah membentuk 23 desa dan 18 kelurahan yang menjadi pilot project Smart Kampung dan saat ini sedang disiapkan untuk 176 desa lainnya. (banyuwangikab.go.id). Berdasarkan Peraturan Bupati Banyuwangi No 18 Tahun 2016 tentang Integrasi Program Berbasis Desa/Kelurahan, ruang lingkup program kerja pemerintah Kabupaten Banyuwangi pada tujuh kriteria berikut, yaitu (1) pelayanan publik, (2) pemberdayaan ekonomi, (3) kesehatan, (4) pendidikan, seni, dan budaya, (5) peningkatan kapasitas sumber daya manusia, (6) kemiskinan, dan (7) informasi hukum. Selain ruang lingkup program kerja tersebut, program Smart Kampung dapat diintegrasikan dengan program dan kegiatan yang disesuaikan dengan kondisi sosial budaya setempat. Pengembangan Smart Kampung didasarkan pada program yang menyentuh langsung pada kepentingan publik dan berbasis pada penggunaan teknologi informasi yang terintegrasi.

Kabupaten Bondowoso melakukan inovasi penggunaan tekhnologi informasi melalui pembuatan aplikasi Sistem Administrasi Informasi Desa yang selanjutnya di sebut SAID. Program ini merupakan kolaborasi inovatif antara Universitas Jember, Kolaborasi Masyarakat dan kesejahteraan layanan (KOMPAK) dan Bantuan Australia. Tujuan dari Sistem Administrasi Informasi Desa (SAID) adalah untuk membentuk desa mandiri dalam data dan informasi 
sehingga desa memiliki data jumlah orang miskin yang akan menjadi dasar bagi pemerintah dalam merumuskan program kemiskinan, pengenalan potensi desa, dan pemasaran produk-produk unggulan desa. Kabupaten Bondowoso telah membentuk 10 desa yang menjadi proyek percontohan Sistem Administrasi Informasi Desa (SAID) di Kecamatan Wringin dan Cermee. Program percontohan ini kemudian direplikasi oleh Pemerintah Kabupaten Bondowoso dengan memperluas penerapan Sistem Administrasi Informasi Desa di 62 desa di seluruh Kabupaten Bondowoso. (Bondowosokab.go.id).

Penelitian terdahulu terkait E-Government telah banyak dilakukan diantaranya penelitian yang banyak menjelaskan mengenai pengembangan konsep E-Government melaui beberapa model pengembangan (Zaidi, 2012). E-government telah muncul sebagai slogan populer dalam administrasi publik untuk mencakup bidang fungsional seperti pemberian layanan, interaktivitas, desentralisasi, transparansi, dan akuntabilitas. Larson and Grounlund (2014) juga menunjukkan bahwa teknologi memainkan peran sentral dalam pengembangan sektor publik; ini dapat bertindak baik sebagai enabler maupun sebagai penghalang untuk keberlanjutan. Implementasi sistem e-government dan aplikasi yang sesuai membutuhkan perolehan keterampilan baru dari pegawai pemerintah (Kim dan Grant, 2010). Perbedaan penelitian ini terletak pada Keberhasilan praktek E-Government di Daerah khususnya di Kabupaten Banyuwangi dan Kabupaten Bondowoso hingga pada tingkatan desa melalui program Smart Kampung dan SAID.

\section{METODE PENELITIAN}

Penelitian ini menggunakan metode penelitian kualitatif. Penelitian kualitatif bertujuan untuk menggambarkan suatu fenomena sosial tertentu sehingga peneliti dapat menggambarkan realitas sosial atau fenomena yang terjadi dengan menggunakan data-data yang ada (Al-Wazir dan Zheng, 2012). Penelitian kualitatif lebih ditujukan untuk masalah yang belum jelas, populasi yang sedikit, dan pada cakupan wilayah yang terbatas (Wang dan Liao, 2008).

Penelitian ini dilakukan dalam ruang lingkup pemerintah Kabupaten Banyuwangi dan Bondowoso terutama yang terkait dengan program Smart Kampung di Kabupaten Banyuwangi dan Program SAID di Kabupaten Bondowoso. Penelitian ini dilakukan pada tingkatan organisasi pemerintah dan individu. Organisasi dalam penelitian ini yaitu Badan Pemberdayaan Masyarakat dan Pemerintahan Desa Kabupaten Banyuwangi dan Bondowoso, Desa/Kelurahan yang telah menjalankan program Smart Kampung di Kabupaten Banyuwangi dan Bondowoso. Pada tingkatan individu, yaitu masyarakat Kabupaten Banyuwangi dan Bondowoso di desa/kelurahan yang telah menjalankan program Smart Kampung dan SAID.

\section{HASIL ANALISIS DAN PEMBAHASAN}

Program Smart Kampung merupakan salah satu program ungulan yang dimiliki oleh pemerintah Kabupaten Banyuwangi. melalui program Smart Kampung diharapkan berbagai kegiatan pelayanan dilakukan secara terintegrasi dan online serta memberikan nilai tambah dalam penyelenggaraan pemerintah desa. Pelaksanaan program Smart Kampung, beberapa kegiatan yang dapat dilaksanakan oleh pemerintah desa dapat dilihat pada Tabel 1.

189 desa yang ada di Kabupaten Banyuwangi, terdapat 23 desa yang telah melaksanakan program Smart Kampung sampai tahun 2015. Tahun 2016 dipersiapkan 19 desa untuk melaksanakan program Smart Kampung tahap II, sedangakan pada tahun 2017 ditargetkan ada 50 desa siap untuk melaksanakan program Smart Kampung. Beberapa desa di Kabupaten 
Tabel 1

Pelaksanaan Kegiatan Smart Kampung

\begin{tabular}{|c|c|c|c|}
\hline No & Kegiatan & Akses & Keterangan \\
\hline 1 & Surat Menyurat Online & portal.banyuwangikab.go.id & $\begin{array}{l}\text { Sudah berjalan dan digunakan untuk } \\
\text { keperluan pelayanan surat menyurat } \\
\text { (keterangan usaha, keterangan pindah } \\
\text { tempat dan SKKB) }\end{array}$ \\
\hline 2 & Produk Hukum & jdih.banyuwangikab.go.id & Belum pernah upload \\
\hline 3 & SPM Online & tkpk.banyuwangikab.go.id & $\begin{array}{l}\text { Sudah siap melaksanakan namun sejauh } \\
\text { ini belum pernah ada pemohon }\end{array}$ \\
\hline 4 & e-village budgeting & evb.banyuwangikab.go.id & Sudah berjalan \\
\hline 5 & $\begin{array}{l}\text { Akta Kelahiran dan } \\
\text { Akta Kematian Online }\end{array}$ & akta.banyuwangikab.go.id & $\begin{array}{l}\text { Sudah berjalan dan sudah ada hasil jadi } \\
\text { berupa akta kematian dan akta kelahiran } \\
\text { yang dikirim langsung ke kantor desa }\end{array}$ \\
\hline
\end{tabular}

Banyuwangi belum siap menjalankan Smart Kampung. Hal ini terkait dengan ketersediaan jaringan internet fiber optik yang belum menjangkau desa-desa tersebut. Jaringan internet merupakan salah satu infrastruktur mendasar yang dibutuhkan dalam pelaksanaan program Smart Kampung di Kabupaten Banyuwangi. Smart Kampung yang didasarkan pada penggunaan teknologi informasi dan juga integrasi data antar lini pemerintahan membutuhkan adanya jaringan internet.

Hal lain yang menjadi perhatian dalam pelaksanaan program Smart Kampung sesuai dengan Peraturan Bupati Banyuwangi nomor 18 Tahun 2016 tentang Integrasi Program Kerja Berbasis Desa/ Kelurahan Melalui Smart Kampung yaitu terkait ketersediaan sarana dan prasarana yang harus disiapkan pemerintah desa. Terdapat beberapa sarana dan prasarana yang harus disiapkan pemerintah desa untuk menjalankan program Smart Kampung, hal ini menjadi perhatian terkait dengan ketersediaan ruang dan lahan kantor desa. Berbagai sarana dan prasarana membutuhkan ketersediaan lahan dan ruang yang cukup luas, sedangkan tidak semua pemerintah desa mamiliki lahan dan ruang yang cukup luas untuk menyediakan semua saran dan prasarana pendukungan program Smart Kampung.

Hal tersebut menjadikan pelaksa- naan program Smart Kampung berbeda di setiap desa dalam hal penyediaan sarana dan prasarana pendukung. Terdapat $2 \mathrm{ka}-$ tegori dalam hal ini, yaitu:

1) Desa yang memiliki lahan dan ruang kantor yang luas akan menyediakan semua sarana dan prasarana pendukung program Smart Kampung, dan

2) Desa yang memiliki lahan dan ruang kantor yang tidak terlalu luas, tidak menyediakan semua sarana dan prasarana pendukung program Smart Kampung.

Desa-desa yang telah menyelenggarakan program Smart Kampung akan menyediakan semua sarana dan prasarana yang dibutuhkan dalam program Smart Kampung, namun bagi desa yang tidak memiliki kecukupan lahan dan ruang akan menyediakan setidaknya jaringan internet dan juga meja resepsionis. Hal ini disesuaikan dengan kebutuhan yang lebih mendesak dalam pelaksanaan program Smart Kampung.

Ketersediaan personil atau sumber daya manusia juga menjadi perhatian dalam pelaksanaan program Smart Kampung di Kabupaten Banyuwangi. Adapun kebutuhan personil dalam penyelenggaraan Smart Kampung yaitu operator dan juga resepsionis serta para kepala dusun /kasun. Resepsionis bertugas sebagai garda terdepan dalam pelayanan pemerintah desa. Melalui resepsionis pelayanan 
akan diterima dan selanjutnya diserakan kepada masing-masing operator. Setelah berkas permohonan pelayanan lengkap dan diproses oleh operator maka pelayanan dapat diproses. Setelah selesai maka produk pelayanan yang diminta dapat diambil melalui resepsionis.

Permasalahan yang ditemukan terkait dengan aplikasi Smart Kampung yaitu belum tersedianya prosedur dan syarat dalam pelayanan, sehingga ketika warga memohon sebuah pelayanan tidak dapat dilihat secara langsung apa saja persyaratan yang dibutuhkan dan juga prosesur yang harus dilalui. Warga pemohon pelayanan harus mengkonfirmasi persyaratan ke resepsionis pelayanan atau ke masing-masing urusan bagian di pemerintahan desa. Standar Operasional Prosedur (SOP) pelayanan belum terbentuk dan tidak adanya aturan atau kewenangan pembentukan SOP pelayanan melalui Smart Kampung. Selain hal tersebut, dalam penggunaan aplikasi Smart Kampung bagi operator belum terdapat buku petunjuk atau pedoman penggunaan aplikasi yang digunakan dalam program Smart Kampung.

Program Smart Kampung belum terintegrasi dengan berbagai data batuan kependudukan dan juga data program jaminan kesehatan dan pendidikan. Sehingga pemerintah desa tidak dapat memetakan prioritas pelayanan kepada masyarakat desa yang lebih membutuhkan. Integrasi data yang ada saat ini berupa integrasi data kependudukan, namun belum pada berbagai bantuan atau data jaminan kesehatan dan pendidikan untuk masing-masing warga.

Akselerasi pemberian layanan kepada masyarakat merupakan salah satu fokus dari Program SAID. Program OID yang terintegrasi dengan penyediaan layanan diharapkan dapat memberikan kepastian, kemudahan dan biaya yang murah hati dalam melakukan layanan. Implementasi layanan yang dilakukan dalam
Program SAID mencakup hampir semua penyediaan layanan kepada masyarakat, apakah itu layanan administrasi atau layanan non-administrasi. Kegiatan-kegiatan OID memberikan nilai lebih dalam pengiriman layanan kepada masyarakat, ada perubahan dalam proses layanan ke layanan digital dan terintegrasi. Adanya dukungan basis data terintegrasi secara keseluruhan akan memberikan kemudahan dan kepastian dalam proses layanan.

Tahapan Proses penyampaian layanan terpadu desa/kelurahan terpadu yang didukung melalui SAID yaitu :

1. Orang-orang datang ke balai desa untuk mendapatkan layanan administrasi seperti KTP atau dokumen lainnya

2. Pemerintah desa memverifikasi data dengan data populasi dan melakukan entri data pemohon menggunakan aplikasi SAID

3. Setelah aplikasi diverifikasi, operator mencetak surat dan meminta tanda tangan kepala desa.

Pengelolaan informasi dan data yang terintegrasi memungkinkan proses yang cepat dan tepat di berbagai tingkat pemerintahan mulai dari tingkat desa/kelurahan, kecamatan hingga kabupaten. Dengan demikian, ada satu kesatuan data dan pembaruan data, karena mendukung proses yang memungkinkan tingkat pemerintahan terendah yaitu desa/kelurahan menjadi sumber dalam input data. Ini mengurangi duplikasi data yang sering menjadi masalah sejauh ini. Desa Cermee, salah satu desa binaan UMD Kompak, yang terletak di perbatasan Kabupaten Bondowoso dan Situbondo unggul dalam layanan unit terintegrasi. Kepala desa Cermee, Sutrisno, mengatakan bahwa layanan publik di tingkat desa semakin efisien setelah penerapan Sistem Administrasi Informasi Desa (SAID), yang mampu mengakomodasi kebutuhan administrasi warga yang dapat dikelola di tingkat desa. Desa Cermee adalah salah satu desa yang memenangkan penghargaan Peng- 
hargaan Manajemen Informasi dan Dokumentasi (PPID) Provinsi pada tahun 2017. Penghargaan ini diberikan oleh pemantauan dan evaluasi Komisi Informasi Provinsi Jawa Timur dari provinsi Jawa Timur dan kantor kabupaten/kota di Jawa Timur. pada 18 Desember 2017. Penghargaan ini diberikan untuk tujuan badan publik untuk meningkatkan PPID dan kualitas layanan informasi publik. Kategori baru yang diberikan pada tahun 2017 adalah pengungkapan informasi desa.

Potensi Desa yang dikembangkan oleh Desa Glingseran adalah pengelolaan dan pengembangan Desa Wisata. Desa Glingseran memiliki potensi alam sebagai objek wisata air terjun. Potensi pariwisata dikembangkan oleh kelompok sadar pariwisata (Pokdarwis). Objek wisata air terjun bernama air terjun sulaiman ini sangat indah bahkan pesona air terjun ini juga mampu menarik perhatian Dinas Pariwisata Bondowoso yang kemudian membantu Pokdarwis mempromosikan Air Terjun Sulaiman sebagai objek wisata baru di Bondowoso. Selain itu, ada juga Tur Taman
Rengganis yang dikatakan sebagai lokasi pemandian dewi legendaris Rengganis. Terletak di tengah sungai dengan pemandangan sawah yang hijau menjadi daya tarik khusus bagi wisatawan. Banyaknya situs megalitik yang menggambarkan peradaban kuno di Bondowoso juga menjadi objek wisata sejarah yang ditawarkan Desa Glingseran.

Menurut sebuah wawancara dengan Kepala Desa Glingseran, Bapak Sulaedi menjelaskan banyak perubahan positif terjadi di desa Glingseran setelah implementasi Universitas Membangun Desa (UMD), sebelum bantuan kami belum menyadari bahwa ada banyak potensi alam sebagai sumber penghasilan bagi kita, dampak lain yang muncul setelah pengembangan pariwisata di desa adalah berkurangnya pengangguran. Selain desa wisata, Desa Glingseran juga mengoptimalkan potensi desa untuk membuat produk unggulan desa berbasis komoditas lokal seperti produksi makanan ringan, minyak kelapa murni, dan kerajinan tangan. Penduduk desa Glingseran

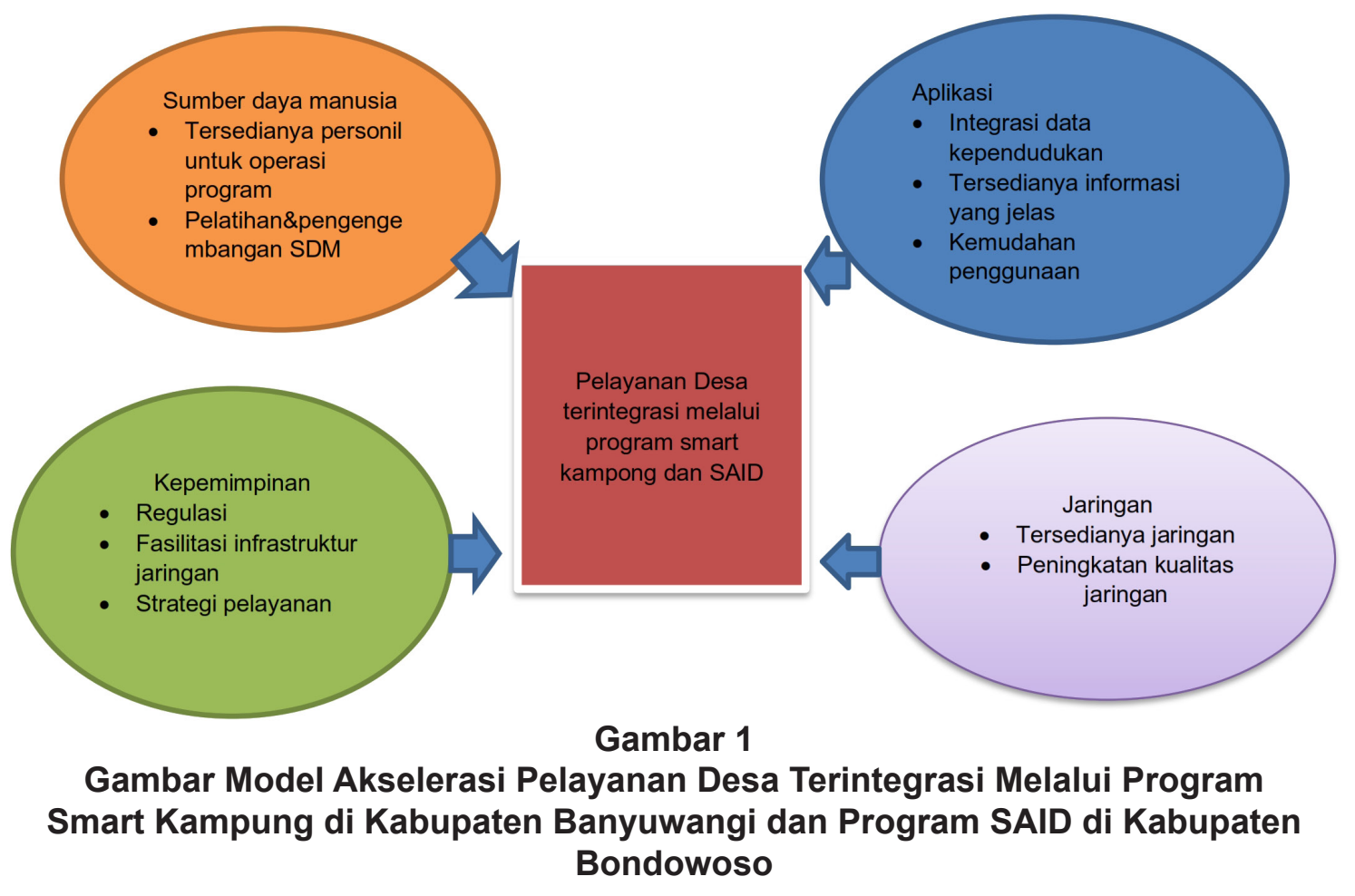


berkomitmen untuk terus mengembangkan potensi wisata mereka dengan menyediakan pengembangan desa melalui situs resmi www.glingseran-bondowoso. desa.id. Berdasarkan hasil peneitian yang dilakukan terhadap pelaksanaan program Smart Kampung di Kabupaten Banyuwangi dan SAID di Kabupaten Bondowoso, maka dapat dilihat beberapa temuan (lampiran).

\section{PENUTUP}

Berdasarkan penjelasan dan analisis mengenai implementasi Smart Kampung dan SAID di Kabupaten Bondowoso dan Kabupaten Bondowoso, dapat disimpulkan bahwa penggunaan Smart Kampung dan SAID di kabupaten bondowoso dan Banyuwangi dapat mewujudkan desa mandiri dalam data dan informasi serta dapat meningkatkan kualitas layanan kepada masyarakat menjadi lebih baik. Desa memiliki basis data yang menjadi rujukan pemerintah kabupaten dalam membuat kebijakan pemberdayaan dan menjadikan layanan kepada masyarakat menjadi lebih cepat, mudah dan murah. Ada beberapa masalah dalam pelaksanaannya seperti desa-desa terpencil yang masih memiliki jaringan internet, rendahnya kompetensi sumber daya manusia di desa, rendahnya dukungan dari pemerintah desa dan kurangnya fasilitas dan infrastruktur.

Berdasarkan hasil analisis maka beberapa Rekomendasi yang penting untuk dilaksanakan diantaranya: Perlunya disusun aturan pelaksanaan program Smart Kampong dan dan SAID berupa petunjuk pelaksanaan dan petunjuk teknis dengan menyusun standar operasional prosedur pelayanan Smart Kampung dan SAID, sehingga terdapat standar yang jelas dalam pelaksanaan pelayanan, Pemerintah Kabupaten Banyuwangi dan Bondowoso mulai melakukan perbaikan basis data dalam hal integrasi berbagai data kependudukan yang tersedia di aplikasi dan sistem yang digunakan dalam program Smart Kampung dan SAID dan
Pemerintah Kabupaten Banyuwangi dan Bondowoso memperkuat jaringan internet yang tersedia dan kecepatan akses data melalui peningkatan bandwith internet.

\section{DAFTAR PUSTAKA}

Al-Wazir, A.A. and Z. Zheng. (2012). Egovernment development in Yemen: assessment and solutions. Journal Emerging Trends Comput Inf Sci, 3(4): 512-518

Anthopoulos, L., Reddick, C. G., Giannakidou, I., dan Mavridis, N. (2016). Why e-government projects fail? An analysis of the Healthcare.gov website. Governement Information Quarterly, 33(1): 161-173.

DeLone, W. H., dan McLean, E. R. (2013). The DeLone and McLean Model of Information Systems Success: A TenYear Update. Jornal of management Information System, 19(4): 9-30.

El-Haddadeh, R., Weerakkody, V., and AlShafi, S. (2013). The complexities of electronic services implementation and institutionalisation in the public sector. Information And Manageent, 50(4): 135-143.

Kim, D.-Y. and Grant, G. (2010). Egovernment maturity model using the capability maturity model integration. Journal of Systems and Information Technology, 12(3):230-244.

Larson and Grounlund. (2014). Sustainable e-Goverment. Governement Information Quarterly, 31(1): 623-642.

Sa, F., Rocha, A., and Cota, M. P. (2015). From the Quality of Traditional Services to the Quality of Local e-Government Online Services: A Literature Review. Government Information Quarterly, 33(1): 1-14.

Wang, Y., and Liao, Y. 2008. Assessing e-government systems success: A 
validation of the DeLone and McLean model of information system success. Government Information Quarterly, 25(4): 717-733.

Zaidi, S., and Qteishat, M. (2012). Assessing e-Government Service Delivery (Government to Citizen). International Journal of eBussiness and eGovernment Studies, 4(1): 45-54. 


\section{Lampiran}

Temuan Pelaksanaan Program Smart Kampung dan Program SAID

\begin{tabular}{|c|c|c|c|}
\hline No & Variabel & Indikator & Penjelasan \\
\hline \multirow[t]{3}{*}{1} & $\begin{array}{l}\text { Kepemimpin } \\
\text { an }\end{array}$ & Komitmen Kades & $\begin{array}{l}\text { - Penyediaan sarana, prasarana dan } \\
\text { infrastuktur } \\
\text { - Desa yang memiliki kantor dan lahan } \\
\text { luas mampu menyedian semua sarana } \\
\text { dan prasarana penunjang } \\
\text { Desa yang memiliki lahan dan kantor } \\
\text { tidak begitu luas setidaknya } \\
\text { menyediakan jaringan internet dan } \\
\text { meja resepsionis }\end{array}$ \\
\hline & & Komitmen Pemda & $\begin{array}{l}\text { - Fasilitasi MoU/kerjasama antara desa } \\
\text { dengan telkom }\end{array}$ \\
\hline & & Anggaran & 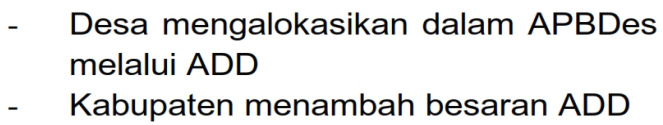 \\
\hline \multirow[t]{2}{*}{2} & SDM & Petugas & $\begin{array}{l}\text { - Kepala Dusun seharusnya langsung } \\
\text { melayani masyarakat namun yang } \\
\text { terjadi pelayanan dilakukan di kantor } \\
\text { desa } \\
\text { - } \quad \text { Penyediaan resepsionis dan operator } \\
\text { - } \quad \text { Resepsionis dan operator dapat } \\
\text { berasal dari perangkat desa dan juga } \\
\text { merekrut pegawai baru }\end{array}$ \\
\hline & & Pelatihan & $\begin{array}{l}\text { - Pemda melakukan pelatihan kepada } \\
\text { operator terkait sistem yang digunakan } \\
\text { dalam program Smart Kampung }\end{array}$ \\
\hline \multirow[t]{5}{*}{3} & Aplikasi & $\begin{array}{l}\text { Kemudahan } \\
\text { penggunaan }\end{array}$ & Portal yang ada mudah digunakan \\
\hline & & $\begin{array}{l}\text { Kelengkapan } \\
\text { aplikasi }\end{array}$ & $\begin{array}{l}\text { - Pada setiap menu pelayanan belum } \\
\text { menyediakan prosedur dan } \\
\text { persyaratan pelayanan }\end{array}$ \\
\hline & & & $\begin{array}{l}\text { - Belum terdapat pedoman pelaksanaan } \\
\text { secara rinci tentang portal dan aplikasi } \\
\text { yang terdapat pada program Smart } \\
\text { Kampung }\end{array}$ \\
\hline & & Integrasi data & $\begin{array}{lll}\text { - } & \begin{array}{l}\text { Terintegrasi dengan } \\
\text { kependudukan }\end{array} & \text { data }\end{array}$ \\
\hline & & & $\begin{array}{l}\text { - Belum terintegrasi dengan data } \\
\text { bantuan yang sudah diterima masing- } \\
\text { masing warga }\end{array}$ \\
\hline \multirow[t]{2}{*}{4} & Jaringan & $\begin{array}{l}\text { Penggunaan } \\
\text { jaringan }\end{array}$ & 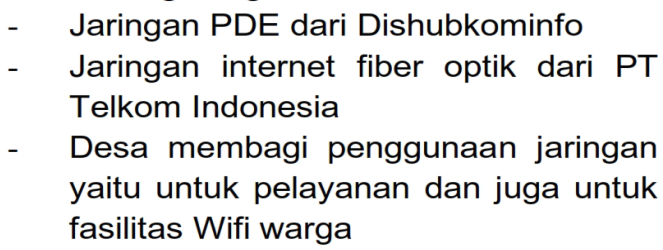 \\
\hline & & Kualitas jaringan & $\begin{array}{l}\text { - Jaringan PDE sering mengalami } \\
\text { gangguan pada saat jam pelayanan } \\
\text { atau menjadi lebih lambat } \\
\text { - Jaringan internet fiber optik terkadang } \\
\text { mengalami masalah jaringan }\end{array}$ \\
\hline
\end{tabular}

